\title{
Overview on life cycle methodologies and economic feasibility for nZEBs
}

\author{
Marta Maria Sesana*, Graziano Salvalai \\ Politecnico di Milano, Department of Architecture, Built Environment and Construction Engineering, Via Ponzio 31, 20133 Milan, Italy
}

\section{A R T I C L E I N F O}

\section{Article history:}

Received 8 April 2013

Received in revised form

16 May 2013

Accepted 28 May 2013

\section{Keywords:}

European directive

Life cycle methodology

Economic feasibility

Nearly zero energy building

\begin{abstract}
A B S T R A C T
The recast Directive on the energy performance of buildings (EPBD) stipulates that by 2020 all new buildings constructed within the European Union after 2020 should reach nearly zero-energy levels. This means that in less than one decade, all new buildings will demonstrate very high energy performance and their reduced or very low energy needs will be significantly covered by renewable energy sources. Such change is affecting both the nature of the built environment as well the actual method of designing and constructing a facility. The economic feasibility to realize a sustainable construction need to have a clear support by adequate analyses connected to the energy consumption and consequently to the new target reductions in greenhouse gas emissions for buildings. Life Cycle Methodologies (LCMs) are currently not considered in details on the EPBD recast, but according also to recent researches, they might be important tasks in a future recast. The paper analyses this challenge providing an overview on the main LCMs to individuate principles, limitations and implications of these approaches to design a Nearly Zero Energy Building (nZEB).
\end{abstract}

(c) 2013 Elsevier Ltd. All rights reserved.

\section{Introduction}

Buildings account for around 40\% of total energy consumption and $36 \%$ of $\mathrm{CO}_{2}$ emissions in Europe. Therefore, reduction of energy consumption and the use of energy from renewable sources in the buildings sector constitute important measures needed to reduce the European Union's energy dependency and greenhouse gas emissions [1]. The mitigation potential of emissions from buildings is important and as much as $80 \%$ of the operational costs of standard new buildings can be saved through integrated design principles.

Due to these increasing awareness of the contemporary development model on climate change effects and the growing international movement towards high performance buildings, the current paradigm of building is changing rapidly.

Abbreviations: nZEB, nearly zero energy building; NZEB, net zero energy building; EPBD, energy performance of buildings directive; LCM, life cycle methodology; LCA, life cycle assessment; LCEA, life cycle energy analysis; LCC, life cycle costs; LC-ZEB, life cycle zero energy buildings; EROI, energy return of investment; EYR, energy yield ratio; EOL, end of life.

* Corresponding author. Tel.: +39 034148 8739; fax: +390341 488731.

E-mail addresses: marta.sesana@polimi.it (M.M. Sesana), graziano.salvalai@ polimi.it (G. Salvalai).
This newly emerging approach differs from established practice in the following important ways: by selecting project team members on the basis of their eco-efficient and sustainable building expertise; greater focus on global building performance than on building systems; a strong emphasis on environmental protection for the whole life-cycle of a building; careful consideration of worker health and occupant health and comfort throughout all phases; scrutiny of all decisions for their resource and life-cycle implications; the added requirement of building commissioning, and a real emphasis on reducing construction and demolition waste $[2,3]$. In assessing the performance of buildings, the scope of environmental evaluation is widening, marking an evolution from a single criterion consideration, like the economic performance of buildings, towards a full integration of all aspects emerging during the lifetime of a building and its elements. Dimitris et al. [4] stated that "Sustainable Buildings" is a broad, multi-criteria subject related to three basic interlinked parameters: economics, environmental issues, and social parameters. Other researches [5-10] remarked and demonstrated moreover the importance of the early design stage of the building itself to reach a responsible and saving energy use, which could be affected e.g., by the geometric form or the functional and aesthetic integration of renewable energy systems [11].

The economical analysis of a construction project allows the feasibility evaluation of the monetary resources being applied, in 
term of investment and/or future costs (operation, maintenance, etc.), considering equally technical liable options for construction. The analysis gives the investor a more realistic and comprehensive approach about the investment he is about to make and the results in terms of building use. The main objective of this paper is to understand how the zero energy concept for building design is interpreted into the economical field.

A research conducted by Ecofis on Nearly Zero Energy Buildings asserted that an LCA for nZEB is definitely far beyond the current intention of the EPBD, but might be in a future recast. The paper analyses this challenge providing an overview of the main Life Cycle Assessment (LCA) and Life Cycle Energy Analyses (LCEA) and their implications for the nZEB design.

The main life cycle methodologies and analyses are presented to understand how it is possible to limit construction costs still creating sustainable and nearly zero energy buildings and also to verify if the estimation of eco-costs against intended value is a useful way of evaluating ex ante the ecological impact of the building during the development design process.

\section{Zero energy concept: principles and perspectives}

The recast of the Energy Performance of Buildings Directive (EPBD) [1] introduced, in Article 9, "nearly Zero Energy Buildings" (nZEB) as a future requirement to be implemented from 2019 onwards for public buildings and from 2021 onwards for all new buildings. The EPBD recast defines in the article 2 a nearly ZeroEnergy Building as a "building that has a very high energy performance $[. .$.$] . The nearly zero or very low amount of energy required$ should to a very significant extent be covered by energy from renewable sources, including renewable energy produced on-site or nearby".

Torcellini et al. [12] defined the concept of net zero energy building (NZEB) as a building that over a year is neutral because it generates as much energy as its overall energy consumption, over a typical year. The adequate methodology, which in practice may lead to zero energy, depends on choosing the adequate technical strategies that respond to defined objectives in a specific context [13]. For this reason in fact the main typologies of NZEB are classified into: site-ZEB and source-ZEB depending on where the energy balance is calculated [14].

The paper provides in this section a clarification on terminology, principles and implications currently in use about "nearly" and "net zero energy" building in order to avoid confusion, since the existing definition for buildings among EU Member States have common approaches, but significant differences, which could leaves plenty of room for interpretation and misunderstanding.

\subsection{Zero energy concept and its implications on the economical, ecological fields}

Within the built environment the term "net energy" is often used to describe a balance between energy used by the building and its occupants and systems and energy produced by its renewable energy systems. However the original concept of "net energy", as it is used in the field of ecological economics, has a very different meaning. It relates to whole life cycle energy accounting and has been evolving for more than a century, currently remaining a widely discussed topic, particularly in the fields of renewable energy and biofuels [15]. The first notions of the concept of "net energy" can be attributed to Podolinsky who tried to analyse aspects of society and the production of goods, mostly related to agriculture, in energy terms [16]. His research could be considered as the first 'net energy' study in history: he tried to relate thermodynamic principles to economic production by considering the "accumulated solar energy" of human activity.

The concept of net energy was again revisited and properly formulated in 1970 with a profound influence in the field of ecological economics.

Georgescu-Roegen introduced the entropy law to economic theory [17-19] and ecologist Howard T. Odum, working on energy flow analysis, stated its own definition, with a great impact at the time on US policy [20].

Since the revival of the 'net energy' concept in the 1970s, net energy analysis has been applied in many different fields, from the fossil fuel and nuclear industries to renewable technologies [2123], being recognized as a valuable tool to consider life cycle aspects of energy systems. The net energy analysis has been defined as a 'technique for evaluating which seeks to compare the amount of energy delivered to society by a technology to the total energy required to find, extract, process, deliver, and otherwise upgrade that energy to a socially useful form' [24].

Different methods and degrees of accuracy have been used for net energy analysis over the years and results have being expressed in different terms such as energy payback or energy return of investment (EROI) of energy production technologies (i.e. Mulder and Hagens [25]) or energy yield ratio (EYR) as the most adequate indicator (i.e. Richards and Watt [26]).

\subsection{Zero energy concept and its implications on building construction sector}

In the building construction field the concept of zero energy (ZEBs) has received increasing attention in recent years, until becoming part of the energy policy in several countries. In the recast of the EU Directive on Energy Performance of Buildings (EPBD) [1] it is specified that by the end of 2020 all new buildings shall be "nearly zero energy buildings". However, despite the emphasis on the goals the definitions remains in most cases generic and are not yet standardized.

Historical definitions of zero energy are based mainly on annual energy use for the building's operation (heating, cooling, ventilation, lighting, etc.). The term net-zero energy is frequently used to present the annual energy balance of a grid-connected building but it does not consider the energy inputs to deliver the building and its components. As such it is not directly associated with the use of the term net energy as related to life cycle energy accounting and as defined in ecological economics and in the renewable energy field [15].

Energy evaluation of buildings typically only considers the energy use in the form of electricity or fossil fuels for the operation of a building without considering the other energy inputs from building construction process as, for example, the manufacturing of materials [15]. Some voluntary environmental assessment methods such as LEED (US Green Building Council) [27] or BREEAM (Building Research Establishment) [28], do account for a wider perspective than annual energy in use and include issues such as material selection, transport, and usage, in these cases they considered the net energy analyses indirectly. The "net energy" concept have been considered in the last decades in a more direct approach using the embodied energy in buildings, which is referred to as energy necessary to deliver products and services. Detailed LCA tools such as SIMAPRO [29] or ATHENA Environmental Impact Estimator (EIE) [30] or BEES 3.0 [31], have been developed which offer the possibility of analysing, in detail, a wide range of environmental aspects of materials including embodied energy, gathered in most cases through life cycle inventory analysis such as described in ISO 14040 [32] and relative standards [33] and [34]. 


\section{Energy, costs and building construction: overview on life cycle methodologies (LCMs)}

Ever since the Brundtland report (1987) [35] stated that sustainable development is the "development that meets the needs of the present without compromising that ability of future generations to meet their own needs", the importance of the Sustainable approach has been consistently increasing. It brings economic, environmental and social concerns together looking to stimulate the equilibrium between the three dimensions. In this perspective, sustainable construction doesn't look for an excellent environmental performance sacrificing economic viability of a company, or an excellent financial performance at the expense of important adverse environ- mental and social effects.

According to Pinheiro [36], sustainable construction takes into account the total life cycle of the asset and considers that the resources of construction are materials, soil, energy and water. From these resources, Kibert [37] established the five basic principles of sustainable construction:

- Reduce resource consumption;

- Reuse resources whenever it is possible;

- Recycle materials at the end of the building's life and use recyclable resources;

- Protect natural systems and its function in all activities;

- Eliminate toxic materials and its by products in every life cycle phase.

Traditional construction is mostly concerned with cost, time and quality. Sustainable construction adds to those criteria the minimization of the use of scarce resources and environmental degradation, and also the creation of a healthy built environment [37]. According to Godfaurd [38], sustainable construction involves the consideration of the building's life cycle because the minimization and reduction of the impacts on nature depends on the performance of the building during all its phases. Following these consideration, this paragraph presents a critical overview on life cycle methodologies: life cycle assessments (LCA), life cycle energy analysis (LCEA), life cycle ZEB (LC-ZEB) and life cycle costs (LCC).

\subsection{Life cycle assessment}

Buildings demand energy in their life cycle right from its construction to demolition. The overall environmental impacts of buildings extend beyond the use phase, as they also encompass the embodied energy and environmental burdens related to resource extraction and manufacturing, construction activities, as well as dismantling and construction waste disposal at end of life (EOL). Moreover, life cycle impacts are highly inter-dependent, as one phase can influence one or more of the others. For instance, the selection of building materials can reduce heat requirement, but might also increase embodied energy and transport-related impacts or affect the service duration of the whole building, and could even influence the generation of recyclable (or disposable) demolition waste [39].

The idea of a comprehensive assessment of products and processes emerged in the 19th century in the context of the development of thermodynamics, the description of ecosystems and in the field of process engineering, which had its roots in chemical engineering. The methods used in life cycle assessment today can be traced back to ecological accounting and industrial energy analysis [40].

In fact, Life Cycle Assessment (LCA) is considered a process whereby the material and energy flows of a system are quantified and evaluated. Typically, upstream (extraction, production, transportation and construction), use, and downstream (deconstruction and disposal) flows of a product or service system are inventoried first. Subsequently, global and/or regional impacts (e.g., global warming, ozone depletion, eutrophication and acidification) are calculated; based on energy consumption, waste generation, etc.; LCA allows for an evaluation of impacts of different processes and life cycle stages on the environment [41].

Referring to the construction sector, an overall judgement on building sustainability should encompass all the life phases and should be based on an objective and internationally recognized and standardized methodology such as ISO 14040 and 14044 standards [32-34]. The recent and growing number of studies [41-52] on life cycle methodologies demonstrate the interest in understanding energy use, consumption of natural resources and pollutant emissions in a life cycle perspective. Therefore, some of this studies [4247] highlighted that operation energy is by far the most important contributor (80-90\%) to life cycle impacts of conventional buildings instead of $10-20 \%$ for the embodied. While some others [48-52], it has been pointed out that, especially for low energy buildings, the relative role and the importance of life cycle phases are changing.

Hernandez and Kenny [15] further observed that low energy buildings perform better than self-sufficient building in life cycle context. In case of self-sufficient house, though its operating energy is zero, its embodied energy is so high that it exceeded life cycle energy of some of the low energy cases. This indicates that selfsufficient house is not the lowest life cycle energy consumer among all versions of a building and there is a limit for life cycle energy savings through reduction in operating energy by installing complex and energy intensive technical installations [43].

\subsection{Life cycle energy analysis (LCEA)}

LCEA is an approach that accounts for all energy inputs to a building in its life cycle. The system boundaries of this analysis include the energy use of the following phases: manufacture, use, and demolition.

Manufacture phase includes manufacturing and transportation of building materials and technical installations used in erection and renovation of the buildings. Operation phase encompasses all activities related to the use of the buildings, over its life span. These activities include maintaining comfort condition inside the buildings, water use and powering appliances. Finally, demolition phase includes destruction of the building and transportation of dismantled materials to landfill sites and/or recycling plants.

Buildings consume energy directly or indirectly in all phases of their life cycle right from the cradle to the grave and there is interplay between phases of energy use (embodied and operating energy).

Ramesh et al. [41] observed that energy savings from recycling or reusing the demolished building materials is not considered in the life cycle energy estimation of the buildings. This is primarily due to the fact that there is no common agreement over attributing this saved energy to the demolished building. However, it would be more appropriate if this energy from recycling or reusing is incorporated in the life cycle energy estimation in overall sense. Studies on the life cycle energy use of the building are desirable, to evaluate strategies for reduction in energy requirement of the buildings and to achieve the zero energy balance. By performing life cycle energy analysis, the phases that have highest energy demand can be identified and targeted for improvement.

\subsection{Life cycle costs (LCC)}

Life cycle cost (LCC) is an approach that assesses the total cost of an asset over its life cycle including initial capital costs, maintenance costs, operating costs and the asset's residual value at the end of its life. Nowadays, most builders are only concerned with the 
initial capital costs (land, project and construction costs), working towards their minimization. The same logic can be applied to sustainable building. This leads to an emphasis on the initial cost, in detriment of the other life cycle costs, and, in some cases, to the supporting of solutions that require smaller investment but have higher operational costs (such as the application of less insulation resulting in higher need for heating and cooling energy) and also lower sustainable levels (like higher carbon emissions).

Life Cycle Costing is an economic methodology for selecting the most cost-effective design alternative over a particular time frame, taking into consideration its construction, operation, maintenance, replacement, rehabilitation costs and also residual value.

According to the Royal Institute of Chartered Surveyors (1983), the objectives of LCC are:

- To enable investment options to be more effectively evaluated;

- To consider the impact of all costs rather than only initial capital costs;

- To assist in the effective management of completed buildings and projects;

- To facilitate choice between competing alternatives.

As a reference, Gupta [53] mentions that approximately $75 \%$ of the life cycle cost of an asset is related to the operation and maintenance phase, which makes unavoidable the consideration of life cycle cost when analysing an asset. If costs are analysed in an equilibrated perspective of the life cycle it is understandable that the application of sustainability to the construction industry without sacrificing the economic component is a reachable reality and is of extreme importance.

In reality, few are the companies that seek to produce buildings with high quality and durability, due to the size of the initial investment needed to ensure reduced operation and maintenance costs. As the builder is usually not the final user of the asset, construction costs are supported by a different entity than operation and maintenance costs, thus the builder doesn't have any advantage in implementing such measures, raising his costs in order to reduce the costs of others [54].

Despite the advantages that the LCC methodology brings to sustainable construction, it has found limited application so far.

The main problem identified was the lack of reliable information and the difficulty in forecasting over a long period of time factors such as life cycles, future operating, maintenance and demolition (especially if it is selective) costs and discount rates. This difficulty is worsened by the difficulty in obtaining the appropriate level of information and data. Therefore, the treatment of uncertainty in information and data becomes crucial to the implementation of LCC [55].

Another limitations for the LCC approach is the variability of the following aspects as highlighted by their respective literature:

- Construction costs of the same component or materials (depending on the company, the quantity and the availability in the specific context of the materials needed) [56-58];

- Maintenance and disposal costs [59,60];

- Energetic savings (depending on several aspects, such as having other buildings next to the studied one or not, and the location of the dwelling in the building) [61-63];

- Component life cycle and performance [64-67].

\subsection{Life cycle zero energy building (LC-ZEB)}

Hernandez and Kenny questions in different researches [15] [68] that building regulations and standards are evolving towards zero energy, but focussing only on energy in use and ignoring factors such as embodied energy. They stated the urgency of integrating a life cycle aspect within current building energy assessment and rating methods to design low energy and 'zero energy buildings' as expressed, for example, in the International Energy Agency policy recommendations on energy efficiency as issued to the G8 [69]. Many countries have established strategies towards 'low energy' or 'zero energy' buildings (i.e. UK Code for Sustainable Home - Zero Carbon - 2016 [70]) and key regulatory schemes such as the recast of the EPBD, nonetheless these declared goals, a standard definition of 'zero energy' or 'nearly zero energy' building does not exist. The definitions are multiple and varied, but always focus on the energy use of the buildings in operation, without considering energy use in other parts of the life cycle, such as manufacturing, construction, maintenance, disposal, etc. This life cycle aspect is however increasingly important as buildings use larger quantities of materials and systems to achieve 'zero energy' in operation, and therefore should be included within building energy assessment and rating methods.

Many researches have been developed on this topic considering different point of views. Casals [71] studied the integration of a life cycle perspective with regulations and certification proposing a rational approach to the assignment of the regulated limits on allowed building energy consumption, integrated with the overall national energy consumption and coherent with the established environmental constraints. He stated that the most suitable approach, that can give us some chances to successfully overcome the environmental constraint to our development process, is a national allocation plan of greenhouse gas emissions between the different sectors should be carried out, assigning the allowed contribution to the building sector, and performing an integral energy assessment on the building to compile with this limitation.

In parallel Zold and Szalay [72] proposed to include the embodied energy related to operation, taking into account the "price" of the improved thermal performance. This could make the optimisation of life-cycle energy use possible and gives more freedom to the designer to"play"with the factors of energy balance. A precondition of a regulation of this type is the standardisation of the calculation of embodied energy.

Hernandez and Kenny [15] proposed an appropriate methodology called LC-ZEB defined as a building whose primary energy use in operation plus the energy embedded in materials and systems over the life of the building is equal or less than the energy produced by renewable energy systems within the building. They chose primary energy as the indicator for annual energy use in operation and for embodied energy because it allows differentiation between electricity and fossil fuel use and it includes an indication of the efficiency of delivering heating, hot water, lighting, etc. The main advantage of this methodology is that it allows building designers to carry out comparative analysis of the life cycle relevance of design decisions related to building envelope design, materials, HVAC and renewable energy systems. All such components can be included in the analysis through their annualized embodied energy and annual energy use.

The main problem is that the building regulations and standards are evolving towards zero energy, focussing on energy in use only and ignoring factors such as embodied energy; while the methodology presented proposes that a life cycle perspective should be considered.

Comparing with other researches on the topic [73-77], the LCZEB provides a model and definition of a simplified methodology to account for embodied energy together with energy use in operation and reclaims the original concept of net energy to define a life cycle zero energy building. 
Table 1

Strengths and weaknesses of life cycle methodologies for nZEBs.

\begin{tabular}{|c|c|c|}
\hline Methodology & Strengths & Weaknesses \\
\hline LCA (life cycle assessment) & $\begin{array}{l}\text { LCA was not originally conceived as a tool for analysis } \\
\text { buildings or process; nevertheless, its applicability in } \\
\text { this sector is accelerating rapidly, and it is currently } \\
\text { considered one of the major tools supporting the efforts } \\
\text { towards achieving sustainable buildings and it has a } \\
\text { significant contribution regarding environmental concerns. }\end{array}$ & $\begin{array}{l}\text { Generally the application of LCA may be limited by its } \\
\text { complexity and a lack of: } \\
\text { - Appropriate acknowledgement of its necessity/utility, } \\
\text { - Specialized knowledge, } \\
\text { - Necessary budget and } \\
\text { an appropriate database. }\end{array}$ \\
\hline $\begin{array}{l}\text { LCEA (life cycle energy } \\
\text { assessment) }\end{array}$ & $\begin{array}{l}\text { LCEA, if quantified in terms of primary energy, can give a } \\
\text { useful indication of the greenhouse gas emissions attributable } \\
\text { to buildings and therefore its impact on the environment. }\end{array}$ & $\begin{array}{l}\text { For broader environmental impact analysis, LCA of } \\
\text { buildings is more useful and appropriate than LCEA. }\end{array}$ \\
\hline LCC (life cycle costs) & $\begin{array}{l}\text { LCC approach presents itself as way to define a low cost } \\
\text { sustainable buildings and the literature showed that the } \\
\text { decisions might be significantly different if LCC analyses are } \\
\text { included in the design process. }\end{array}$ & $\begin{array}{l}\text { LCC presents some limitations such as lack of reliable } \\
\text { information and difficulty in forecasting over a long } \\
\text { period of time factors. To deal with these problems } \\
\text { there are various risk assessment techniques, the most } \\
\text { used ones are: } \\
\text { - Sensitivity Analysis (deterministic approach), } \\
\text { - Monte Carlo Simulation (probabilistic approach) } \\
\text { - Fuzzy Set Theory. }\end{array}$ \\
\hline $\begin{array}{l}\text { LC-ZEB (life cycle - zero } \\
\text { energy building) }\end{array}$ & $\begin{array}{l}\text { LC-ZEB provides a model and definition of a simplified } \\
\text { methodology to account for embodied energy together with } \\
\text { energy use in operation and reclaims the original concept of } \\
\text { net energy to define a life cycle zero energy building. } \\
\text { The integration of LC-Building Energy Ratio [68] could have } \\
\text { also an impact on practices in new construction and } \\
\text { refurbishment not only as the reduced energy use in } \\
\text { operation is rewarded with better rating, but also the use of } \\
\text { materials or technologies with a low embodied energy and } \\
\text { a high "Net Energy Ratio". }\end{array}$ & $\begin{array}{l}\text { Building regulations, energy directives and standards } \\
\text { are evolving towards zero energy considering only the } \\
\text { energy in use and ignoring factors such as embodied } \\
\text { energy that LC-ZEB include in its life cycle methodology. }\end{array}$ \\
\hline
\end{tabular}

\section{Discussions and conclusions}

As remarked earlier, the environmental burden and, by consequence, life cycle approaches and eco-costs relate to all phases of the life cycle of buildings; this statement emphasise the need for systematically verifying the environmental performance of future low energy building using a holistic approach.

The nZEB design process would certainly benefit from the adoption of a life cycle methodologies, but it should be kept in mind that excessive generalisations, blind reliance on user-friendly tools and non-transparent databases still remain a limitation to their diffusion.

In order to find an answer to the economical question regarding what the sustainability of construction world concerns, this paper clarifies the nearly Zero Energy concept in the ecological/ economical sphere and it provides a critical overview of the life cycle methodologies currently known (LCEA, LCA, LCC and LC-ZEB).

Following the main strengths and weaknesses, for each approach described, are briefly summarized in Table 1.

In conclusion it is important to remark that all of these approaches still needs further researches to embrace the Zero Energy Building Design to overcome their limitations and they also requires a valid database to permit more applicability and diffusion of these methodologies.

\section{References}

[1] EPBD recast. Directive 2010/31/EU of the European Parliament and of the Council of 19 May 2010 on the energy performance of buildings (recast). Official Journal of the European Union 2010. 18/06/2010.

[2] Kibert CJ. Sustainable construction: green building design and delivery. New Jersey, Unisted States of America: John Wiley \& Sons; 2005.

[3] Mateus R, Bragança L. Sustainability assessment and rating of buildings: developing the methodology SBTool ${ }^{\mathrm{PT}}-\mathrm{H}$. Building and Environmen 2011;46:1962-71.

[4] Dimitris A, Giama E, Papadopoulos A. An assessment tool for the energy, economic and environmental evaluation of thermal insulation solutions. Energy and Buildings 2009;41(10):1165-71.

[5] Mwasha A, Williams RG, Iwaro J. Modeling the performance of residential building envelope: the role of sustainable energy performance indicators. Energy and Building 2011;43(9):2108-17.
[6] Pisello AL, Goretti M, Cotana F. Building energy efficiency assessment by integrated strategies: dynamic simulation, sensitivity analysis and experimental activity. In: Proceedings of third international conference on applied energy, 16-18 May 2011-Perugia, Italy. p. 1395-1412.

[7] Sesana MM, Salvalai G, Esposito F. A sensitivity analyses approach on an Italian case study: the simulations as tools for the design process, In: PLEA 2011, 27th international conference on passive and low energy architecture, Louvain-laNeuve, Belgium, July 13-15, 2011, ISBN: 978-2-87463-277-8. p. 223-228.

[8] Fabrizio E, Corrado V, Filippi M. A model to design and optimize multi-energy systems in buildings at the design concept stage. Renewable Energy 2010;35(3):644-55.

[9] Zhao H, Magoulès F. A review on the prediction of building energy consumption. Renewable and Sustainable Energy Reviews 2012;16(6):3586-92.

[10] Srinivasan RS, Braham W, Campbell DE, Curcija CD. Re(De)fining net zero energy: renewable energy balance in environmental building design. Building and Environment 2012;47:300-15.

[11] Hachem C, Athienitis A, Fazio P. Parametric investigation of geometric form effects on solar potential of housing units. Solar Energy 2001:85(9):1864-77.

[12] Torcellini P, Pless S, Deru M, Crawley D. A critical look at the definition, ACEEE summer study on energy efficiency in buildings. Golden, CO: National Renewable Energy Laboratory; 2006.

[13] Cellura M, Ciulla G, Lo Brano V, Orioli A, Campanella L, Guarino F, et al. The redesign of an Italian building to reach net zero energy performances: a case study of the SHC task 40-ECBCS Annex 52, (ML-11-C040). ASHRAE Transactions 2011;117. (Part 2).

[14] Crawley D, Pless S, Torcellini P. Getting to net zero. ASHRAE Journal September 2009. NREL/JA-550-46382.

[15] Hernandez P, Kenny P. From net energy building: defining life cycle zero energy buildings (LC-ZEB). Energy and Buildings 2010;42(6):815-21.

[16] Podolinsky S. Socialism and the unity of physical forces. Organization \& Environment 2004;17(1):61-75.

[17] Georgescu-Roegen N. The entropy law and the economic process. Cambridge, MA: Harvard University Press; 1971.

[18] Daly HE. On Nicholas Georgescu-Roegen's contributions to economics: an obit- uary essay. Ecological Economics 1995;13(3):149-54.

[19] Cleveland CJ, Ruth M. When, where, and by how much do biophysical limits constrain the economic process? A survey of Nicholas Georgescu-Roegen's con- tribution to ecological economics. Ecological Economics 1997;22(3): 203-23.

[20] Odum HT. Energy, ecology, and economics. AMBIO: A Journal of the Human Environment 1973;2(6):220-7.

[21] Cleveland CJ. Net energy from the extraction of oil and gas in the United States. Energy 2005;30(5):769-82.

[22] Lenzen M. Life cycle energy and greenhouse gas emissions of nuclear energy: a review. Energy Conversion and Management 2008;49(8):2178-99.

[23] Crawford RH, Treloar GJ. Net energy analysis of solar and conventional domestic hot water systems in Melbourne, Australia. Solar Energy 2004;76(13):159-63. 
[24] Cleveland C. (Lead Author), Costanza R. (Topic Editor). Net energy analysis. In: Cleveland CI, editor. Encyclopedia of Earth, environmental information coalition, national council for science and the environment. Washington, DC [First published in the Encyclopedia of Earth September 14, 2006; Last revised August 22, 2008; Retrieved August 30, 2009] <http://www.eoearth.org/ article/Net_energy_analysis $>$.

[25] Mulder K, Hagens NJ. Energy return on investment: toward a consistent frame- work. AMBIO: A Journal of the Human Environment 2008:74-9.

[26] Richards BS, Watt ME. Permanently dispelling a myth of photovoltaics via the adoption of a new net energy indicator. Renewable and Sustainable Energy Reviews 2007;11(1):162-72.

[27] US Green Building Council. Leadership in energy and environmental design (LEED) green building rating system, http://www.usgbc.org/LEED.

[28] Building Research Establishment. BRE environmental essessment method, www.breeam.org.

[29] Pre Consultants. SIMAPRO, http://www.simapro.com/.

[30] ATHENA Institute. ATHENA impact estimator, http://www.athenasmi.ca.

[31] BEES (Building for environmental and economic sustainability), http://www. nist.gov/el/economics/BEESSoftware.cfm.

[32] ISO 14040. Environmental management - life cycle assessment - principles and framework. Geneva, Switzerland: International Organization for Standardization; 2006.

[33] DIN EN ISO 14040. Environmental management - life cycle assessment principles and framework directive? Building and Environment 2007;42(4): 1761-9.

[34] ISO 14044. Environmental management - life cycle assessment - requirements and guidelines. Geneva, Switzerland: International Organization for Standardization; 2006.

[35] UNWCED. United Nations World Commission on environment and development. Our Common Future (Brundtland Report). Oxford University Press; 1987.

[36] Pinheiro M. Ambiente e Construção Sustentável. Lisboa: Instituto do Ambiente; 2006. (Conselho Cientifico: Correia, F. N., Branco, F., Guedes, M.).

[37] Kibert C. Establishing principles and a model for sustainable construction. In: Kibert CJ, editor. Proceedings of the first international conference on sustainable construction 1994. CIB TG 16.

[38] Godfaurd J, Clements-Croome D, Jeronimidis G. Sustainable building solutions: a review of lessons from the natural world. Building and Environment 2005;40(3):319-28.

[39] Blengini GA, Di Carlo T. The changing role of life cycle phases, subsystems and materials in the LCA of low energy buildings. Energy and Buildings 2010;42(6):869-80.

[40] Koenig H, Kohler N, Kreibbig J, Luetzkendorf T. A life cycle approach to buildings - principles, calculations and design tools. Regensburg: Detail Green Books; 2010.

[41] Ramesh T, Prakash R, Shukla KK. Life cycle energy analysis of buildings: an overview. Energy and Buildings 2010;42(10):1592-600.

[42] Blengini GA. Life cycle of buildings, demolition and recycling potential: a case study in Turin-Italy. Building and Environment 2009;44(2):319-30.

[43] Sartori I, Hestnes AG. Energy use in the life cycle of conventional and lowenergy buildings: a review article. Energy and Buildings 2007;39(3):249-57.

[44] Ortiz O, Bonnet C, Bruno JC, Castells F. Sustainability based on LCM of residential dwellings: a case study in Catalonia, Spain. Building and Environment 2009;44(3):584-94.

[45] Blanchard S, Reppe P. LCA of a Residential Home in Michigan. Michigan: School of Natural Resources and Environment, University of Michigan; 1998. p. 60.

[46] Adalberth K, Almgren A, Petersen EH. Life cycle assessment of four multifamily buildings. International Journal of Low Energy and Sustainable Buildings $2001 ; 2$.

[47] Maddox B, Nunn L. Life cycle analysis of clay brick housing based on a typical project home. New Castle: The Centre for Sustainable Technology, University of New Castle; 2003.

[48] Chen TY, Burnett J, Chau CK. Analysis of embodied energy use in the residential building of Hong Kong. Energy 2001;26(4):323-40.

[49] Winther BN, Hestnes AG. Solar versus green: the analysis of a Norwegian row house. Solar Energy 1999;66(6):387-93.

[50] Mithraratne N, Vale B. Life cycle analysis model for New Zealand houses. Building and Environment 2004;39(4):483-92.

[51] Citherlet S, Defaux T. Energy and environmental comparison of three variants of a family house during its whole life span. Building and Environment 2007;42(2):591-8.
[52] Huberman N, Pearlmutter D. A life-cycle energy analysis of building materials in the Negev desert. Energy and Buildings 2008;40(5):837-48.

[53] Gupta YP. Life cycle cost models and associated uncertainties, electronics systems effectiveness and life cycle costing. In NATO ASI Series 1983.

[54] Real SF, Pinheiro MD. Life cycle cost as base to define low cost sustainable building solutions. In: Proceedings of sustainable building, low cost sustainable solutions, affordable to all, Portugal SB10, Villamoura, 16th - 19th March 2010.

[55] Kishk M, Al-Hajj A, Pollock R, Aouad G, Bakis N, Sun M. Whole life costing in construction: a state of the art review. UK: RICS; 2003.

[56] Schade J. Life cycle cost calculation models for buildings. In: Proceedings of 4th Nordic conference on construction economics and organisation: development processes in construction management. Luleå tekniska universitet; 2007. p. 321-9.

[57] Ehlen M. Life-cycle costs of new construction materials. Infrastructure System 1997;4:129-33.

[58] Hastak M, Halpin DW. Assessment of life-cycle benefit-cost of composites in construction. Journal of Composites for Construction 2000;4(3):103-11.

[59] Bettini F, Amerighi O, Burchi B, Butto P. A methodological approach to life cycle costing of an innovative technology: from pilot plant to industrial scale: ENEA Italian National Agency for New Technologies, Energy and Sustainable Economic Development, ISBN 978-88-8286-270-1. p. 57-64.

[60] El-Diraby. Web-services environment for collaborative management of product life-cycle costs. Journal of Construction Engineering and Management 2006;132(3):300-13.

[61] Hachem C, Athienitis A, Fazio P. Evaluation of energy supply and demand in solar. Energy and Buildings 2012;49:335-47.

[62] Reich MC. Economic assessment of municipal waste management systemscase studies using a combination of life cycle assessment (LCA) and life cycle costing (LCC). Cleaner Production 2005;13(3):253-63.

[63] Raymond JC, Sterner E. Reconciling theory and practice of life cycle costing. Building Research \& Information 2000;28:368-75.

[64] Keoleian GA, Blanchard S, Reppe P. Life-cycle energy, costs, and strategies for improving a single-family house. Journal of Industrial Ecology 2000;4: 135-56.

[65] Thiebat F. Life-cycle methods as design tools for sustainability assessment of technologies, what is sustainable technology? The role of life cycle-based methods in addressing the challenges of sustainability assessment of technologies: ENEA Italian National Agency for New Technologies, Energy and Sustainable Economic Development, ISBN: 978-88-8286-270-1. p. 72-74.

[66] De Kleine RD, Keoleian GA, Kelly JC. Optimal replacement of residential air conditioning equipment to minimize energy, greenhouse gas emissions, and consumer cost in the US. Energy Policy 2011;39(6):3144-53.

[67] InPro - Open information environment for knowledge-based collaborative processes throughout the lifecycle of a building, EU integrated project, 026716-2 6th Framework Programme, http://www.inpro-project.eu.

[68] Hernandez P, Kenny P. Development of a methodology for life cycle building energy ratings. Energy Policy 2011;39(6):3779-88.

[69] Jollands N, Waide P, Ellis M, Onoda T, Laustsen J, Tanaka K, et al. The 25 IEA energy efficiency policy recommendations to the G8 Gleneagles plan of action. Energy Policy 2010;38(11):6409-18.

[70] Code for sustainable homes and energy performance of buildings, www communities.gov.uk.

[71] Casals XG. Analysis of building energy regulation and certification in Europe: their role, limitations and differences. Energy and Buildings 2006;38(5):381-92.

[72] Zold A, Szalay Z. What is missing from the concept of the new European Building Directive? Building and Environment 2007;42(4):1761-9.

[73] Cole RJ, Kernan PC. Life-cycle energy use in office buildings. Building and Environment 1996;31(4):307-17.

[74] Adalberth K. Energy use during the life cycle of single-unit dwellings: examples. Building and Environment 1997;32(4):321-9.

[75] Harris DJ. A quantitative approach to the assessment of the environmental impact of building materials. Building and Environment 1999;34(6):751-8.

[76] Thormark C. A low energy building in a life cycle - its embodied energy, energy need for operation and recycling potential. Building and Environment 2002;37(4):429-35.

[77] Itard L, Klunder G. Comparing environmental impacts of renovated housing stock with new construction. Building Research \& Information 2007;35(3): 252-67. 